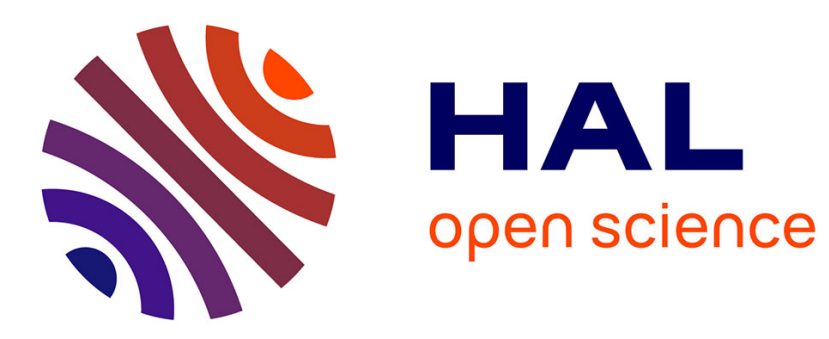

\title{
Improved wheat grain yield by a new method of root selection
}

\author{
Anna Heřmanská, Tomáš Středa, Oldřich Chloupek
}

\section{To cite this version:}

Anna Heřmanská, Tomáš Středa, Oldřich Chloupek. Improved wheat grain yield by a new method of root selection. Agronomy for Sustainable Development, 2015, 35 (1), pp.195-202. 10.1007/s13593014-0227-4 . hal-01284250

\section{HAL Id: hal-01284250 \\ https://hal.science/hal-01284250}

Submitted on 7 Mar 2016

HAL is a multi-disciplinary open access archive for the deposit and dissemination of scientific research documents, whether they are published or not. The documents may come from teaching and research institutions in France or abroad, or from public or private research centers.
L'archive ouverte pluridisciplinaire HAL, est destinée au dépôt et à la diffusion de documents scientifiques de niveau recherche, publiés ou non, émanant des établissements d'enseignement et de recherche français ou étrangers, des laboratoires publics ou privés. 


\title{
Improved wheat grain yield by a new method of root selection
}

\author{
Anna Heřmanská • Tomáš Středa • Oldřich Chloupek
}

Accepted: 31 March 2014 / Published online: 25 April 2014

(C) INRA and Springer-Verlag France 2014

\begin{abstract}
Wheat is a major source of protein for human food, a critical issue at a time when mankind is growing by 77 million people per year. Wheat was domesticated approximately 10,000 years ago and has been systematically bred for about 200 years. However, this breeding selection has been done using only aerial plant parts. Indeed, wheat roots, the hidden half of plant, were not considered in breeding programs due to the lack of an appropriate method. Here, we evaluated roots of 18 wheat populations. The root system size was measured by its electrical capacitance directly in field. The plants in third and fourth generations were evaluated during shooting and heading. Then plants were selected for large and small root system. In dry conditions, progeny of plants with large and small root system had yields of 17.1 and $10.9 \mathrm{~g}$ per plant in the third generation and 18.5 and $10.0 \mathrm{~g}$ per plant in the fourth generation. Our results show that the progeny of the plants selected for large roots have larger roots than their parents, also in next generation. Similarly, the progeny of small root plants have smaller roots. The selection process showed a greater response for larger root system size. This response can be evolutionarily advantageous and make selection easier than, for example, selection for grain yield. Our unique method enables accurate, repeated evaluation and harvest of selected plants. Selection for higher wheat root system size can be easily used to breed for drought tolerance and higher efficiency of water and fertilizer use.
\end{abstract}

Keywords Winter wheat $\cdot$ Selection response $\cdot$ Root system size $\cdot$ Electrical capacitance $\cdot$ Drought tolerance

A. Heřmanská

Plant Breeding Station, SELGEN, Úhřetice, Czech Republic

T. Středa $(\varangle) \cdot$ O. Chloupek

Mendel University in Brno, Zemědělská 1, 61300 Brno, Czech Republic

e-mail: streda@mendelu.cz

\section{Introduction}

According to the United Nations, the world population exceeded the 7 billion in 2011 and it is currently growing by approximately 77 million people per year. Globally, wheat is the leading source of vegetable protein in human food. The annual production gain will need to reach near $2.5 \%$ by the year 2025 to keep abreast of population growth (Curtis et al. 2002). Plant protein is cheaper with lower consumption of water and energy in comparison with animal protein. However, the current and projected relative progress rates in yield enhancement, under potentially low water conditions, are a topic of considerable concern. Yields are expected to be insufficient to meet the projected demand for cereals by 2050 (Hall and Richards 2013). The low yield capacity of contemporary farming systems is a major obstacle to the future growth of sustainable agriculture (e.g., Fasoula and Tokatlidis 2012). The availability of nitrogen is largely determined by root densities, and mineral fluxes are generally reduced under conditions of water deficit (Gonzalez-Dugo et al. 2010). The grain yield of winter wheat varieties in dry years is generally positively correlated with root system size, but this correlation is negative in certain environments. In a dry year, the varieties that showed the greatest difference in root system size were found to exhibit a yield difference of $860 \mathrm{~kg} \cdot \mathrm{ha}^{-1}$, approximately translating to an additional use of $15 \mathrm{~mm}$ of subsoil water (Středa et al. 2012).

Cereals are shallow-rooting plants. In experiments by Bodner et al. (2010), root density in a shallow layer was 4.6, 6.3 , and $8.6 \mathrm{~cm} \cdot \mathrm{cm}^{-3}$ for vetch, mustard, and rye, respectively. A significant positive correlation was found between root biomass and $\mathrm{P}$ and $\mathrm{K}$ uptake. Wheat genotypes with superior root characteristics for efficient nutrient uptake, especially during tillering and booting stages, should be developed in breeding programs to increase grain yield and to minimize nitrate leaching (Ehdaie et al. 2010). 
Crossing early green-revolution wheat to an $\mathrm{F}_{2}$ of Norin 10 or Brevor reduced root biomass. Later-generation semi-dwarf wheat showed genetic variation for root biomass, but some generations exhibited a further reduction in root size (Waines and Ehdaie 2007). These results support our research and suggest practical breeding methods.

We proposed that roots should be evaluated during the shooting and heading stages, times when nutrient requirements are the highest because of the rapid increase in biomass. Furthermore, the selected plants should be harvested for reproduction and used to develop new varieties. We previously developed and applied an electrical capacitance method to evaluate the size of the intact root system in the soil (Chloupek 1972). The aim of our research was to repeatedly evaluate wheat root system size during practical field selection and to determine its effect on grain yield.

1.1 Evaluation of root system size in soil by measuring its electrical capacitance

\subsubsection{Theory}

During its passage through a substance, alternating electric current encounters an impedance barrier consisting of ohmic resistance, capacitance, and inductance. While inductance is not present in plant tissues, resistance and capacitance are separate, but parallel impedance factors. Therefore, plant tissue shows parallel capacitance, and its electrical capacity is measured in micro and nanofarads. The greater the mutual area of the capacitor plates, the smaller their mutual distance, and the higher the permittivity (dielectric constant) of the dielectric between the plates, the greater the capacitance. Water, paper (cellulose), and air gaps have very different permittivities, with relative values of 80,3 , and 1 , respectively. The permittivity of cellulose increases with its water content and depends on the frequency $(\mathrm{kHz})$ at which the capacitance is measured (e.g., Guegan and Foulc 2009). Over a range of $7-1,000 \mathrm{~Hz}$, the ratio of the capacitive to resistive components of tissue impedance in excised muscle was greatest at $1 \mathrm{kHz}$ (Schwan and Kay 1957). Therefore, we used $1 \mathrm{kHz}$ in our study. Lipid bilayers, the basic structural elements of cell membranes, are the basis for many of the properties of these membranes. The formation of the membrane is indicated by an increase in its electrical capacity. The approximate value of electrical capacity for biological membranes is $0.9 \mu \mathrm{F} \cdot \mathrm{cm}^{-2}$ (Montal and Mueller 1972). This uniform, specific electric capacity of biological membranes per unit area inspired Chloupek (1972) to evaluate the relationship between root system size and electrical capacitance. Roots and other plant tissues have been found to respond in a manner similar to that of cylindrical conductors and parallel-plate capacitors at a frequency of $1 \mathrm{kHz}$. Notably, the age of the plants has been found to have little effect on the dielectric properties of maize tissues (Walker 1965).

These data show that the measured capacitance reflects not only root size but also membrane vitality, as dying membranes lose capacitance.

\subsubsection{Application}

Chloupek (1972) evaluated the correlation between root system size (fresh and dry weight, and volume and surface area) and electrical capacity $(C)$ in maize, sunflower, oat, and onion. The measurements of electrical capacity were performed in the soil in which the plants grew. The highest correlation was found for parallel capacitance at $1 \mathrm{kHz}$. Dvoř́ák et al. (1981) and Zhang et al. (1995) demonstrated a positive relationship between the area of plant membranes and their electrical capacity in a plant-soil system. In measurements of electrical capacity, Dalton (1995) suggested that roots form columnar capacitors, the epidermis forms external electrodes, and the xylem forms internal electrodes that are analogous to the plates of a capacitor. Dying and dead yeast cells showed low capacitance (Patel et al. 2008).

More studies, cited by Chloupek et al. (2010), report a significant correlation between root size and its capacitance. Recently, Cseresnyés et al. (2012) reported the correlation between electric capacitance and root dry mass $\left(R^{2}=0.937\right)$ and root surface area $\left(R^{2}=0.893\right)$ in maize. Ellis et al. (2013) reported the following important findings: (i) the root system was the primary constituent of the measurements and (ii) the root system acted as the capacitor. The relationship between the electrical capacitance and the area of the stem bases was weak. They found that the evaluation of electrical capacitance is a rapid and nondestructive method of root size evaluation because the capacitance was significantly correlated with root mass, length, and surface area. However, the predictive power of electrical capacity in this scenario was poor. The entire root system contributed to the measured electrical capacity, and the measured permittivity dictated the value found in the plant tissue. These results supported Dalton's model, where the measured electrical capacity was a parameter of the root system.

The isolation of intact living root systems from the soil in the field has not yet been performed and appears to be impossible (Fig. 1). We are unaware of any method suitable for the repeated evaluation of root system size in the same plant at different developmental stages or the evaluation of many plants in segregated populations, an important prerequisite for successful practical breeding. The selected plants must be able to produce seeds for evaluation and reproduction in subsequent generations. These requirements were satisfied by the method used in this study. Repeated evaluations decreased the inaccuracy of the method. Ellis et al. (2013) reported errors in the range of $69-79 \%$. Using the average of two or three 
Fig. 1 Electrical capacitance of root system measured in relation to the surrounding soil includes also root hairs which cannot be evaluated by excavating from the soil (roots of wheat; enlarged)

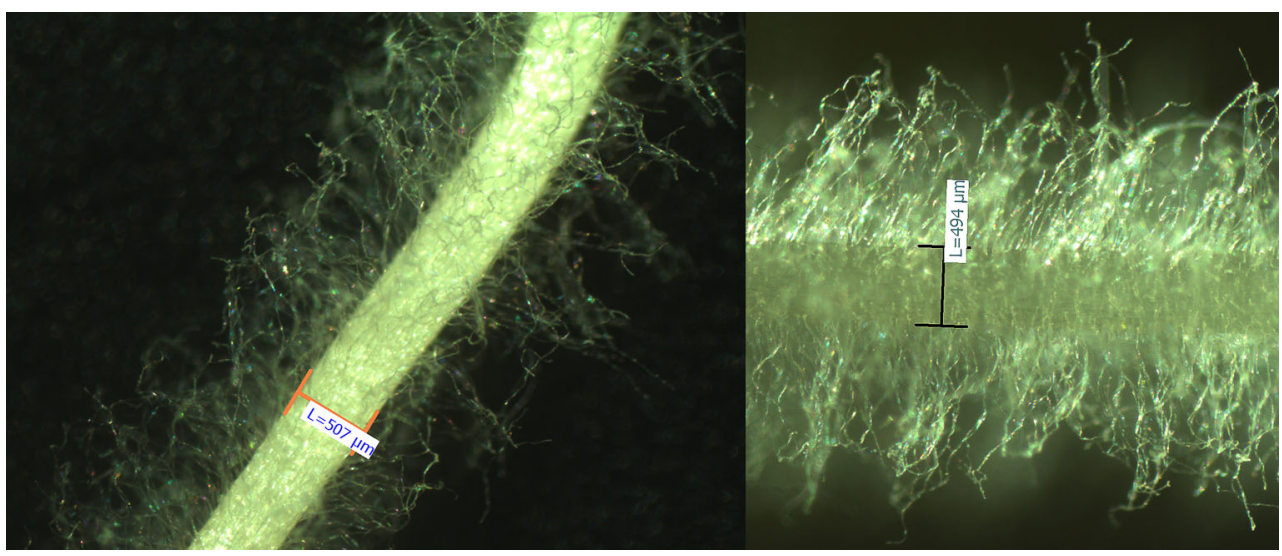

measurements taken during the vegetative period would decrease this error range to $48-62 \%\left(69^{2}-79^{2}\right)$ and $23-38 \%$ $\left(48^{2}-62^{2}\right)$, respectively. Because breeders evaluate selected progeny in multiple generations, the resulting lines may have a significantly greater root system size.

\section{Materials and methods}

\subsection{Plant selection}

Six varieties (Akteur, Meritto, Sakura, Simila, Sulamit, and Vlasta) were mutually crossed at the Plant Breeding Station Úhretice in the Czech Republic in the Central Europe in 2008. The resulting 18 populations were sown in the field on October 13,2008 , and harvested as $F_{1}$ generation on July 29 , 2009. In 2009 , the $F_{2}$ generation was sown at three stations, Úhretice

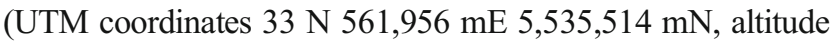
235-258 m.a.s.l., medium loamy degraded chernozem soilaccording to IUSS Working Group WRB 2007 classification), Chlumec nad Cidlinou (Chlumec; UTM coordinates $33 \mathrm{~N}$ 534,999 mE 5,554,784 mN, altitude 235-254 m.a.s.l., medium and light loamy and loamy-sand haplic luvisol soil), and Hustopeče (UTM coordinates $33 \mathrm{~N} 626,018 \mathrm{mE}$ $5,419,581 \mathrm{mN}$, altitude 183-246 m.a.s.1., light loamy-sand chernozem soil). Root system size was not evaluated in 2010 due to rainy weather, particularly in April and May. The $F_{2}$ generation was harvested only in Úhřetice on August 13, 2010. The $\mathrm{F}_{3}$ generation was sown on October 12,14 , and 8, 2010, at Úhřetice, Chlumec, and Hustopeče, respectively. In 2011, the root system size was measured in shooting plants on May 11 and 12, and in heading plants on June 3, May 31, and June 5. The plants were harvested on August 15, 12, and 11, 2011, at Úhřetice, Chlumec, and Hustopeče, respectively. For each combination, the plants were separated into A and B selection groups and, with their parents, were sown in the $\mathrm{F}_{4}$ generation at Úhřetice, Chlumec, and Hustopeče on October 18 and 17 and September 28, 2011, respectively. According to data obtained from the nearest climatological station, the Czech
Hydrometeorological Institute, located up to $5 \mathrm{~km}$ away, there was poor emergence caused by heavy drought (Table 1). As a result, the experiments in Úhřetice and Hustopeče were not evaluated. Only the selected progeny in Chlumec were evaluated. Root system size was measured in shooting plants on May 24, 2012, and in heading plants on June 7, 2012. The crop was harvested on August 13, 2012.

Field experiments through the $\mathrm{F}_{4}$ generation were randomly sown by hand in four replicates, with parents in rows consisting of ten plants, spaced at $0.10 \times 0.15 \mathrm{~m}$. During the shooting and heading stages, the root system size was measured in six of the inner plants only. From each replicate of the 18 populations, the two plants with the largest (A) and the two with the smallest (B) roots were selected. Seeds from eight plants from each of the A and B selection groups (four replicates $\times$ two plants) from each of the 18 combinations were bulked and sown similarly in the following generation.

In the $\mathrm{F}_{5}$ generation, the single best $\mathrm{A}$ selection plant of each combination was grown in $0.36-\mathrm{m}^{2}$ plots (three rows $0.80 \mathrm{~m}$ in distance $0.15 \mathrm{~m}$ ). This regular spacing was used because root system size cannot be evaluated if a canopy is present.

All trials were managed according to standard agronomic practices. Nitrogen fertilization varied from 75 to $100 \mathrm{~kg} \cdot \mathrm{ha}^{-1}$. Pesticides were used as needed to control weeds and insects. Herbicide was typically applied in April or May (two applications in Úhřetice 2012/2013). Insecticide was applied from zero to three times (typically once). Fungicide treatments were not applied.

\subsection{Capacitance measurements}

The root system size was measured in nanofarads $(\mathrm{nF})$. One wire of the capacitance meter was connected using a clamp to all the basal parts of the plant of equal height. This height was near the soil but not in contact with it. The second wire, which leads the measuring current to the soil, was grounded in the spacing, midway between the measured plants. An impedance bridge ESCORT ELC-131D LCR meter (Escort Instruments 
Table 1 The meteorological conditions during the experimental years. The average annual (January to December) air temperature $\left({ }^{\circ} \mathrm{C}\right)$, annual rainfall total (mm), and seasonal (March to July) soil moisture, expressed as the percentage of seasonal available soil-water holding capacity are shown. The percentage of available soil water holding capacity is defined as the amount of soil water available for plant use or the water volume between soil water field capacity and permanent wilting point

\begin{tabular}{|c|c|c|c|c|c|c|c|c|c|}
\hline \multirow[t]{2}{*}{ Location } & \multicolumn{3}{|c|}{ Average annual temperature } & \multicolumn{3}{|c|}{ Average annual rainfall } & \multicolumn{3}{|c|}{ Seasonal available soil-water holding capacity (\%) } \\
\hline & 2011 & 2012 & 2013 & 2011 & 2012 & 2013 & 2011 & 2012 & 2013 \\
\hline Hustopeče & 10.0 & 10.2 & 9.7 & 429 & 511 & 528 & 44 & 39 & 56 \\
\hline Úhřetice & 10.0 & 9.8 & 9.2 & 560 & 636 & 587 & 45 & 47 & 89 \\
\hline Chlumec & 10.2 & 9.9 & 9.5 & 556 & 689 & 560 & 38 & 32 & 94 \\
\hline
\end{tabular}

Corporation, Taiwan) was used and set to parallel measured capacitance at a frequency of $1 \mathrm{kHz}$.

\subsection{Evaluation of heritability}

Heritability $\left(h^{2}\right)$ is the percentage of trait variation inherited into progeny. In relation to the parents in the same year, the realized heritability in the root system size in our experiment was calculated from the selection difference in the parental generation $(S)$ and realized difference in progeny $(R): R=h^{2} \cdot S$ (e.g., Falconer 1989). Heritability can also be estimated using the coefficient of determination, the square of the linear correlation coefficient calculated between generations. The realized heritability has a higher relevance for practical breeding.

\subsection{Statistical analysis}

Results of the root system size and grain yield were evaluated using a multifactor analysis of variance and a correlation analysis using STATISTICA statistical software (StatSoft, ver. 7.0, Tulsa, OK, USA). Significant values $(P<0.05)$ are marked with an asterisk $(*)$ and highly significant values $(P<0.01)$ are marked with a double asterisk $(* *)$.

The reliability of our root measurements was compared to that of grain yield measurements using the percentage of the experimental error (unexplained variation) of the whole variation, calculated from standard deviations (root of mean squares in analysis of variance).

\section{Results and discussion}

\subsection{Root system size and crops}

Dietrich et al. (2013) showed that root size could not be evaluated using electrical capacitance because it is strongly influenced by soil moisture. Our data support this statement. In the $\mathrm{F}_{3}$ generation (harvested in 2011), the root system size of all parental varieties was averaged at $3.75 \mathrm{nF}$. The grain yield of the A and B selection groups was 17.10 and $10.90 \mathrm{~g}$ per plant, respectively. However, as shown in Table 2, the root system size was $6.41 \mathrm{nF}$ in the $\mathrm{F}_{4}$ generation (harvested in 2012), with a grain yield of 18.47 and $9.99 \mathrm{~g}$ per plant for $\mathrm{A}$ and $\mathrm{B}$ selections, respectively. The soil moisture analysis showed that the root system size of the $\mathrm{F}_{3}$ generation, at all three stations, was evaluated under moisture-stressed conditions. The amount of seasonal available soil-water holding capacity in shooting and heading stage plants was as follows: 28 and $9 \%$ in Úhřetice, 41 and $9 \%$ in Hustopeče, and 9 and $4 \%$ in Chlumec. The root system size of the $\mathrm{F}_{4}$ generation in Chlumec was evaluated under different soil moisture conditions, 6 and $11 \%$ in shooting and heading plants, respectively. Even if the soil conditions were different in the different years, both the grain yield and root system size measured by electrical capacitance could be reliably compared among the populations produced in the same year.

Walker (1965) found that the root tissue of Zea mays in Hoagland's solution acted like cylindrical conductors and parallel-plate capacitors at a frequency of $1 \mathrm{kHz}$, forming part of the electrical circuit. Therefore, it was unexpected that the capacitance measured was largely determined by the tissue between the surface of the substrate and the electrode attached to the plant (Dietrich et al. 2013), even though they reported a correlation between the electrical capacitance and root size $\left(R^{2}=0.70, n=67\right)$ (Dietrich et al. 2012).

The reliability of our root system size measurements, as a combined percentage of experimental error in $\mathrm{F}_{3}, \mathrm{~F}_{4}$, and $\mathrm{F}_{3}$ and $\mathrm{F}_{4}$ together in the analysis of variance, amounted to $2.9,7.0$, and $6.0 \%$ for the root system size, and 5.6, 9.5, and 6.0\% for grain yield, respectively. Experimental factors we examined were population, selection, and generation (sum of standard deviations for the experimental factors accounted for the remainder of the variation to $100 \%$ ). Therefore, the reliability of both evaluations was similar. Our evaluation of three generations of winter wheat root size and grain yield is shown in Table 2.

The average root system size of $18 \mathrm{~F}_{3}$ populations (2011) was $4.39 \mathrm{nF}$ in A selections, $3.05 \mathrm{nF}$ in B selections, and $3.75 \mathrm{nF}$ in the parents. The average difference in comparison to the parents was +17.1 in A selections and $-18.7 \%$ in $\mathrm{B}$ selections. In the $\mathrm{F}_{4}$ generation (2012), the average root system size in A selections was $6.88 \mathrm{nF}, 6.23 \mathrm{nF}$ in B selections, and $6.41 \mathrm{nF}$ in the parents, an average difference of +7.3 and 
Table 2 Average root system size (in nanofarads; $\mathrm{nF}$ ) of 18 experimental winter wheat populations calculated from two measurements each year. Grain yield (g per plant in $\mathrm{F}_{3}$ and $\mathrm{F}_{4}$, and $\mathrm{g}$ per $0.36 \mathrm{~m}^{2}$ in $\mathrm{F}_{5}$ ) are compared to the parents $\left(\mathrm{F}_{3}\right.$ in 2011, averaged from Chlumec, Úhretice, and Hustopeče and $\mathrm{F}_{4}$ in 2012 from Chlumec)

\begin{tabular}{|c|c|c|c|c|c|c|c|c|c|c|c|c|c|}
\hline \multirow[t]{3}{*}{ Nr. } & \multicolumn{2}{|c|}{ Particular parents } & \multicolumn{5}{|c|}{$\mathrm{F}_{3}$ generation } & \multicolumn{5}{|c|}{$\mathrm{F}_{4}$ generation } & \multirow{3}{*}{$\begin{array}{l}F_{5} \text { generation } \\
\text { A sel. grain yield }\end{array}$} \\
\hline & \multirow[t]{2}{*}{ Female } & \multirow[t]{2}{*}{ Male } & \multirow[t]{2}{*}{ A sel. } & \multirow[t]{2}{*}{ B sel. } & \multirow[t]{2}{*}{ Parents } & \multicolumn{2}{|c|}{ Grain yield } & \multirow[t]{2}{*}{ A sel. } & \multirow[t]{2}{*}{ B sel. } & \multirow[t]{2}{*}{ Parents } & \multicolumn{2}{|c|}{ Grain yield } & \\
\hline & & & & & & A plants & B plants & & & & A plants & B plants & \\
\hline 1 & Akteur & Meritto & 4.36 & 3.02 & 3.93 & 17.12 & 9.98 & 7.52 & 6.44 & 6.78 & 13.32 & 9.50 & 273 \\
\hline 2 & Akteur & Simila & 4.71 & 3.49 & 3.89 & 17.43 & 10.95 & 7.09 & 6.07 & 6.77 & 20.08 & 7.15 & 273 \\
\hline 3 & Akteur & Sakura & 4.56 & 3.18 & 3.92 & 18.29 & 10.71 & 7.04 & 7.07 & 6.44 & 19.47 & 15.43 & 259 \\
\hline 4 & Akteur & Sulamit & 4.80 & 3.34 & 3.84 & 21.13 & 12.69 & 7.36 & 7.05 & 6.99 & 22.61 & 9.13 & 237 \\
\hline 5 & Meritto & Sulamit & 4.18 & 2.88 & 3.55 & 17.41 & 11.92 & 7.25 & 5.78 & 6.05 & 23.33 & 11.40 & 274 \\
\hline 6 & Sakura & Meritto & 4.27 & 2.67 & 3.73 & 17.39 & 9.09 & 7.14 & 5.85 & 5.50 & 18.98 & 11.43 & 211 \\
\hline 7 & Sakura & Simila & 3.84 & 2.81 & 3.69 & 16.14 & 11.47 & 5.52 & 4.43 & 5.49 & 18.03 & 6.78 & 309 \\
\hline 8 & Sakura & Akteur & 4.49 & 3.14 & 3.92 & 15.67 & 10.16 & 7.73 & 6.87 & 6.44 & 18.94 & 13.50 & 278 \\
\hline 9 & Sakura & Sulamit & 4.79 & 3.13 & 3.64 & 19.36 & 12.28 & 6.32 & 5.08 & 5.71 & 18.49 & 8.35 & 267 \\
\hline 10 & Simila & Sulamit & 4.06 & 2.95 & 3.60 & 17.38 & 10.45 & 5.40 & 5.13 & 6.04 & 15.90 & 7.30 & 330 \\
\hline 11 & Simila & Meritto & 4.18 & 2.88 & 3.69 & 20.21 & 13.22 & 7.24 & 5.98 & 5.83 & 24.79 & 12.64 & 242 \\
\hline 12 & Sulamit & Sakura & 3.68 & 2.61 & 3.64 & 12.07 & 9.85 & 6.61 & 6.94 & 5.71 & 17.38 & 12.13 & 206 \\
\hline 13 & Sulamit & Akteur & 4.29 & 3.20 & 3.84 & 14.71 & 11.40 & 7.18 & 6.54 & 6.99 & 20.91 & 6.07 & 243 \\
\hline 14 & Vlasta & Sulamit & 4.69 & 3.12 & 3.62 & 15.42 & 10.70 & 6.17 & 6.62 & 6.99 & 9.20 & 6.84 & 111 \\
\hline 15 & Vlasta & Meritto & 4.66 & 3.32 & 3.71 & 17.07 & 10.65 & 7.60 & 7.00 & 6.78 & 18.57 & 8.55 & 216 \\
\hline 16 & Vlasta & Simila & 4.22 & 2.87 & 3.67 & 17.00 & 10.34 & 5.68 & 5.86 & 6.77 & 15.84 & 11.17 & 231 \\
\hline 17 & Vlasta & Akteur & 4.87 & 3.34 & 3.90 & 18.39 & 10.03 & 7.63 & 6.62 & 7.72 & 16.25 & 15.17 & 242 \\
\hline \multirow[t]{2}{*}{18} & Vlasta & Sakura & 4.34 & 3.03 & 3.70 & 15.53 & 10.34 & 7.29 & 6.03 & 6.44 & 20.37 & 7.26 & 176 \\
\hline & Average & & 4.39 & 3.05 & 3.75 & 17.10 & 10.90 & 6.88 & 6.23 & 6.41 & 18.47 & 9.99 & 243.2 \\
\hline
\end{tabular}

$-2.8 \%$ for $\mathrm{A}$ and $\mathrm{B}$ selections, respectively, in comparison to the parents grown in the same year. Therefore, the progeny of plants selected for larger root system size had a larger root system size, and the progeny of plants selected for smaller root system size had a smaller root system size. The A selection resulted in an inherited increase in root system size of $+7.3 /+$ $17.1=+0.43$ in the following generation, whereas the corresponding result for the B selection was $-2.8 /-18.7=-0.15$. It appears that the selection for larger root system size was more evolutionarily advantageous than that for small root system size. In a similar study using spring barley, Svačina et al. (2014) found that the response to A selection and B selection was +9.8 and $-5.3 \%$, respectively. Here, the response to $\mathrm{A}$ selection in wheat was markedly higher (43\%) than that previously reported for spring barley. We attribute this difference to the selection of $\mathrm{F}_{3}$ generation wheat at the three stations, decreased environmental variation, and increased genetic variation, making the selection more efficient.

Understanding the major limitations placed on root growth is extremely important if we are to maximize water and nutrient use and increase yields. These limitations may include insufficient rooting depth, root diseases, nutrient deficiencies, toxicities, and soil hardness (Richards 2008). Larger investment by the crop in fine roots deep in the soil and less proliferation of roots in surface layers would improve yields by allowing the plant access to extra resources. The economic return on investment for water capture in roots has been found to be twice that of the same amount invested for nitrogen capture (King et al. 2003).

The root system size of parental varieties was significantly correlated with that of the $\mathrm{F}_{3}$ progeny $(\mathrm{A}, \mathrm{B}$, and $\mathrm{A}+\mathrm{B}$ progenies, $R^{2}=0.262^{*}, 0.314^{*}$, and $0.326^{*}$, respectively). These coefficients of determination between close generations can be regarded as coefficients of heritability, the percentage of the genotype inherited by the progeny. The values obtained $(0.26-0.33)$ are relatively high, but such high values are normal when a selection criterion is used for the first time.

Table 3 shows that under A selection, the Simila variety exhibited a decrease in root system size in both generations, whereas Akteur exhibited an increase in root system size. This difference was statistically significant. In our previous work (Středa et al. 2012), we evaluated approximately 20 wheat varieties over 4 years, but only seven in all years. The Akteur variety showed the greatest root system size over the 4 years (2.67 $\mathrm{nF}$, averaged from three measurements, compared to $2.23-2.52 \mathrm{nF}$ in the other six varieties). Therefore, this variety was used in this study and we recommend its use when breeding for greater root system size. 
Table 3 Average root system size (in nanofarads) of populations, for which a particular variety was used as one parent

\begin{tabular}{lllllll}
\hline Variety & $\mathrm{F}_{3}(2011)$ & & & \multicolumn{2}{l}{$\mathrm{F}_{4}(2012)$} & Averaged \\
\cline { 2 - 3 } \cline { 5 - 6 } & $\begin{array}{l}\text { Average of A } \\
\text { populations }\end{array}$ & $\begin{array}{l}\text { Average of B } \\
\text { populations }\end{array}$ & & $\begin{array}{l}\text { Average of A } \\
\text { populations }\end{array}$ & $\begin{array}{l}\text { Average of B } \\
\text { populations }\end{array}$ & \\
\hline Akteur & 4.58 & 3.24 & 7.36 & 6.67 & 5.46 \\
Meritto & 4.33 & 2.95 & & 7.35 & 6.21 & 5.21 \\
Sakura & 4.28 & 2.94 & 6.81 & 6.14 & 5.04 \\
Simila & 4.20 & 3.00 & 6.19 & 5.49 & 4.72 \\
Sulamit & 4.36 & 3.03 & 6.61 & 6.27 & 5.07 \\
Vlasta & 4.56 & 3.14 & 6.87 & 6.43 & 5.25 \\
\hline
\end{tabular}

\subsection{Response to selection}

The response to selection $(R)$ is related to the selection difference in the parental generation $(S)$ and the heritability of the trait $\left(h^{2}\right)$, and is represented by the equation $R=h^{2} \cdot S$ (e.g., Falconer 1989). We evaluated both the selection difference for root system size in relation to the parents and the response to selection similarly in the following generation. As shown above, the heritability was $0.43(+7.3 /+17.1=+0.43)$ under A selection and $0.15(-2.8 /-18.7=-0.15)$ under B selection. The heritability under A selection is similar to the heritability of root system size evaluated by electrical capacitance in maize (50 \%) (Messmer et al. 2011) and is unexpectedly high, perhaps due to evolutionary advantage. Our values of the realized heritability are similar to those calculated from the coefficient of determination for the trait between successive generations $(0.26-0.33)$.

\subsection{Root system size and grain yield}

Root system size was also evaluated in relation to grain yield in $\mathrm{F}_{3}$, as shown in Fig. 2. The correlation was highly significant under A selection $\left(R^{2}=0.423 * * ; \mathrm{P}<0.005\right)$, but not under B selection $\left(R^{2}=0.139\right)$.

Greater root system size needs not to be advantageous in all years for improved grain yield (Středa et al. 2012). Figure 2 shows that the plants under A selection had populations with large root system size and high yield, enabling selection for the trait. Of course, the correlation is not absolute. Of the variation in grain yield, $42 \%\left(R^{2}\right)$ was explained by the root size. Root system size could not be evaluated in $\mathrm{F}_{5}$ because evaluation required regularly spaced plants, not a stand. However, it is more reliable to determine yield in a stand than in spaced plants. The correlation between the yield of the $F_{3}$ and $F_{4}$ combinations was $R^{2}=0.140 *(\mathrm{P}<0.05)$ and was $R^{2}=0.093$ between $\mathrm{F}_{4}$ and $\mathrm{F}_{5}$ in $\mathrm{A}$ selection plants. Therefore, 14 and $9 \%$ of the yield increase caused by larger root system size was inherited into the $\mathrm{F}_{4}$ and $\mathrm{F}_{5}$ generations, respectively. This is normal in polytrait selection for characteristics controlled by many genes, such as grain yield and root system size
(Chloupek et al. 2006). The $\mathrm{F}_{4}$ generation was sown from a bulk of selected plants, but $\mathrm{F}_{5}$ was sown only from one. This could also decrease the inheritance.

Durum wheat showed a stronger response to water availability in fine roots and produced more fine roots in a moist year, and the electrical root capacitance was higher in Khorasan wheat (Ebrahimi et al. 2013). We found genetic differences at the variety level (Středa et al. 2012) and in segregating populations between progeny of the Akteur and Simila varieties. The strategy of increasing post-anthesis dry matter production through an enhancement of root activity during grain filling has been proposed as an approach to increase the grain yield of wheat in China (Li et al. 2012). One of our two measurements was performed near the time of grain filling. A large root system size contributes to increased capture of water and nitrogen early in the season (our first measurement) and facilitates the capture of additional water for grain filling. The usefulness of a vigorous root system in increasing wheat yields under water-limited conditions may

Grain yield (g)

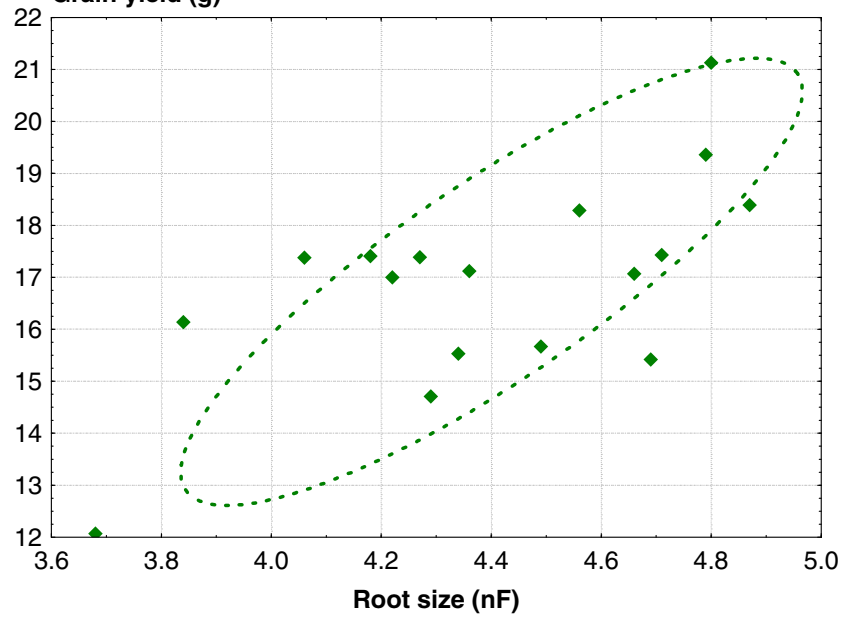

Fig. 2 Regression of grain yield on root system size for the plants under A selection, as averaged from three locations in $2011\left(\mathrm{~F}_{3}\right)$. The scatter plot is shown with $95 \%$ confidence ellipse. The confidence ellipse shows where a specified percentage of the data in a scatter plot will lie. Only 17 averages were evaluated because one progeny had an outlying average. Equation of the linear regression: $y=0.2604+3.784 x$ 
be greater in environments where crops rely largely on seasonal rainfall, such as Mediterranean-type environments (Palta et al. 2011).

As Central Europe experienced two dry years during the 5year experimental period, approximately two fifth of the cereal varieties tested should have greater root system size, according to the results of our studies. Higher seed vigor, evaluated as the percentage of germination under drought and temperature stress, could also contribute to the goal of effective grain yield enhancement (Ullmannová et al. 2013).

We confirmed that selection, including that based on root system size evaluation, might contribute to the goal of increasing grain yield more effectively. These results are in agreement with the previously reported results for barley (Chloupek et al. 2010; Svačina et al. 2014) and wheat (Středa et al. 2012).

\section{Conclusions}

Our results showed that the progeny of the plants selected for large root size in the $\mathrm{F}_{3}$ generation also had larger root system sizes than their parents in the next generation. Similarly, the progeny of plants selected for small root size also had a smaller root system size in the next generation than their parents. The root system size was correlated with grain yield in the $\mathrm{F}_{3}$ generation. These results show an efficient selection for root system size and accompanying effects on grain yield. Such a selection was made possible by using electrical capacitance measurements. This promising selection method can be used to breed for drought tolerance and higher efficiency of water and fertilizer use.

Acknowledgments This work was supported by a project of the Ministry of Agriculture of the Czech Republic, QI111C080.

\section{References}

Bodner G, Himmelbauer M, Loiskandl W, Kaul H-P (2010) Improved evaluation of cover crop species by growth and root factors. Agron Sustain Dev 30:455-464. doi:10.1051/agro/2009029

Chloupek O (1972) The relationship between electric capacitance and some other parameters of plant roots. Biol Plant 14:227-230. doi:10. 1007/BF02921255

Chloupek O, Forster BP, Thomas WTB (2006) The effect of semi-dwarf genes on root system size in field-grown barley. Theor Appl Genet 112:779-786. doi:10.1007/s00122-005-0147-4

Chloupek O, Dostál V, Středa T, Psota V, Dvořáčková O (2010) Drought tolerance of barley varieties in relation to their root system size. Plant Breed 129:630-636. doi:10.1111/j.1439-0523.2010.01801.x

Cseresnyés I, Fekete G, Végh KR, Székács A, Mörtl M, Rajkai K (2012) Monitoring of herbicide effect in maize based on electrical measurements. Int Astrophys 26:243-247. doi:10.2478/v10247-012-0036-4

Curtis BC, Rajaram S, Gómez Macpherson H (2002) Bread wheat. Improvement and production. FAO Plant Production and Protection Series No. 30. FAO, Rome
Dalton FN (1995) In-situ root extent measurements by electrical capacitance methods. Plant Soil 173:157-165. doi:10.1007/BF00155527

Dietrich RC, Bengough AG, Jones HG, White PJ (2012) A new physical interpretation of plant root capacitance. J Exp Bot 63:6149-6159. doi:10.1093/jxb/ers264

Dietrich RC, Bengough AG, Jones HG, White PJ (2013) Can root electrical capacitance be used to predict root mass in soil? Ann Bot 112:457-464. doi:10.1093/aob/mct044

Dvořák M, Černohorská J, Janáček K (1981) Characteristics of current passage through plant tissue. Biol Plant 23:306-310. doi:10.1007/ BF02895374

Ebrahimi E, Bodner G, Kaul H-P, Dabbaqh A (2013) Effects of water supply on roots traits and biological yield of Durum (Triticum durum Desf.) and Khorasan (Triticum turanicum Jakubz) wheat. Plant Biosyst. doi:10.1080/11263504.2013.850120

Ehdaie B, Merhaut DJ, Ahmadian S, Hoops AC, Khuong T, Layne AP, Waines JG (2010) Root system size influences water-nutrient uptake and nitrate leaching potential in wheat. J Agron Crop Sci 196:455466. doi:10.1111/j.1439-037X.2010.00433.X

Ellis T, Murray W, Kavalieris L (2013) Electrical capacitance of bean (Vicia faba) root systems was related to tissue density - a test for the Dalton Model. Plant Soil 366:575-584. doi:10.1007/s11104-0121424-z

Falconer DS (1989) Introduction to quantitative genetics, 3rd edn. Longman, Harlow, $438 \mathrm{p}$

Fasoula VA, Tokatlidis IS (2012) Development of crop cultivars by honeycomb breeding. Agron Sustain Dev 32:161-180. doi:10. 1007/s13593-011-0034-0

Gonzalez-Dugo V, Durand J-L, Gastal F (2010) Water deficit and nitrogen nutrition of crops. A review. Agron Sustain Dev 30:529-544. doi:10.1051/agro/2009059

Guegan Q, Foulc J-N (2009) Electrical characterization of the solid phase (particles) of electrorheological fluids. 11th Conference on Electrorheological Fluids and Magnetorheological Suspensions. J Phys Conf Ser 149, 012006. doi:10.1088/1742-6596/149/1/012006

Hall AJ, Richards RA (2013) Prognosis for genetic improvement of yield potential and water-limited yield of major grain crops. Field Crop Res 143:18-33. doi:10.1016/j.fcr.2012.05.014

IUSS Working Group WRB (2007) World reference base for soil resources 2006, first update. World Soil Resources Reports No. 103. FAO, Rome

King J, Gay A, Sylvester-Bradley R, Bingham I, Foulkes J, Gregory P, Robinson D (2003) Modelling cereal root systems for water and nitrogen capture: towards an economic optimum. Ann Bot 91:383390. doi:10.1093/aob/mcg033

Li H, Liu L, Wang Z, Yang J, Zhang J (2012) Agronomic and physiological performance of high-yielding wheat and rice in the lower reaches of Yangtze River of China. Field Crop Res 133:119-129. doi:10.1016/j.fcr.2012.04.005

Messmer R, Fracheboud Y, Bänziger M, Stamp P, Ribaut J-M (2011) Drought stress and tropical maize: QTLs for leaf greenness, plant senescence, and root capacitance. Field Crop Res 124:93-103. doi: 10.1016/j.fcr.2011.06.010

Montal M, Mueller P (1972) Formation of bimolecular membranes from lipid monolayers and a study of their electrical properties. Proc Natl Acad Sci U S A 69:3561-3566. doi:10.1073/pnas.69. 12.3561

Palta JA, Chen X, Milroy SP, Rebetzke GJ, Dreccer MF, Watt M (2011) Large root systems: are they useful in adapting wheat to dry environments? Funct Plant Biol 38:347-354. doi:10.1071/FP11031

Patel PM, Bhat A, Markx GH (2008) A comparative study of cell death using electrical capacitance. Enzym Microb Technol 43:523-530. doi:10.1016/j.enzmictec.2008.09.006

Richards RA (2008) Genetic opportunities to improve cereal root systems for dry land agriculture. Plant Prod Sci 11:12-16. doi:10.1626/pps. 11.12 
Schwan HP, Kay CF (1957) Capacitive properties of body tissues. Circ Res 5:439-443. doi:10.1161/01.RES.5.4.439

Středa T, Dostál V, Horáková V, Chloupek O (2012) Effective use of water by wheat varieties with different root system sizes in rain-fed experiments in Central Europe. Agric Water Manag 104:203-209. doi:10.1016/j.agwat.2011.12.018

Svačina P, Středa T, Chloupek O (2014) Uncommon selection by root system size increases barley yield. Agron Sustain Dev 34:545-551. doi:10.1007/s13593-013-0160-y

Ullmannová K, Středa T, Chloupek O (2013) Use of barley seed vigour to discriminate drought and cold tolerance in crop years with high seed vigour and low trait variation. Plant Breed 132:295-298. doi:10. $1111 / \mathrm{pbr} .12065$

Waines JG, Ehdaie B (2007) Domestication and crop physiology: roots of green-revolution wheat. Ann Bot 100:991-998. doi:10.1093/aob/ mem180

Walker JM (1965) Electrical A. C. resistance and capacitance of Zea mays L. Plant Soil 23:270-274. doi:10.1007/BF01358354

Zhang MIN, Repo T, Willison JHM, Sutinen S (1995) Electrical impedance analysis in plant tissues: on the biological meaning of ColeCole $\alpha$ in Scots pine needles. Eur Biophys J 24:99-106. doi:10. 1007/BF00211405 